\title{
Experimental Study on Partial Supersede of Bitumen by Waste Materials in Flexible Pavement
}

\author{
Sudha.G ${ }^{1}$, Swetharani. $A^{2}$, Illakkya. $G^{3}$ \\ Civil Department, ACET, Sankarapuram \\ gsudha735@gmail.com ${ }^{1}$,aswetha940@gmail.com ${ }^{2}$, illakkyagunasekaran24@gmail.com ${ }^{3}$
}

\begin{abstract}
Now a day's disposal of waste materials has become issue and great concern for environmental engineering due to non-biodegradable characteristic and health hazards. In this world the various wastes are produced day to day life . the normal ending periods of flexible pavement is 15 years and rigid pavement is 30 years and maintenance work for flexible pavement is high .so we have to equalizes the end period by using various waste materials. Disposal of waste is a menace and it is serious problems. Instead of disposing waste into landfills, it can be reused in flexible pavements. The tests were also performed to check the properties of the aggregates and bitumen. Some replacement percentages have been carried out based on trial and error methods . in our motte is to reduce the waste materials it is used for some purposed thing as well as to reduce the maintenance cost. if burning the waste or land filling the waste, it create air pollution and dumping the waste create hazardous to the groundwater, it pollute the water also so we are managing and creating the healthy and useful environment.
\end{abstract}

KEYWORDS: Replacement of waste materials, Stability,Grading tests for bitumen , Flow values ,Cost analysis.

\section{INTRODUCTION}

The massive development of highway everywhere through the world was going ahead at present century. A good roadway in the foundation of a solid stable financial. In India the construction plays an important role. The construction of building, bridge, roads has some requirement and some design consideration with their standards and codal provision. Mostly two pavement can be used one is rigid and another one is flexible cost wise rigid is very high and life time of rigid is also high there is no maintenance work for rigid pavement . to reduce the cost and making economy by choosing the flexible pavement. We are adding the various waste materials like tire rubber and glass fibre to attain the higher strength Marshall stability test is the important to carryout nominal bitumen and combination of waste materials to measure the stability and flow value. By using waste materials. The developing issue of transfer of this material is an issue that requires coordination and duty by all gathering development of highway however such a utilization ought not to trade off the quality and execution of the roadway framework not being about a domain issue

\section{II.OBJECTIVE OF THE STUDY}

1. To study the grading for nominal bitumen

2. To introduce new innovative construction technical for flexible pavement.

3. To recycle the waste material to partial supersede of bitumen.

4. To improve strength for flexible pavement.
5. To reduce the cost of construction for flexible pavement.

6. To increase the stability and durability of the pavement

7. To know the stability and flow values for nominal and modified bitumen mix by conducting job mix.

\section{LITERATURE REVIEW}

Any study that is undertaken needs a sound back ground research, which helps in understanding the concepts involved and previous research work in area this particular chapter contains a gist of the relevant information that was collected in order to understand the research problem. Research papers published by researches in the area of bitumen and related areas have been referred to gain a thorough understanding of the various method adopted in going about this work .The following section with relevant research work in brief.

G.D.Airey ,T.M.Singleton and A.C.Collop (Aug-2002) " Properties of polymer modified bitumen after rubber bitumen interaction" Investigated the use of rubber tire replacing bitumen. The result indicate the oxidative aging of the control mixture at high temperature has a lesser effects on the materials resistance to degradation 1 to $6 \mathrm{~h}$ there is approximately a $300 \%$ increase in mass loss as compared with approximately $50 \%$ for the sample containing no rubber.

Panagiotis frantzs (Aug 2004) "Crumb rubber bitumen interaction diffusion of bitumen in to rubber" investigated the used of crumb rubber replacing 
bitumen. This method has been developed to study the diffusion of bitumen in to rubber. This allowed determination of the diffusion and solubility coefficients of bitumen in rubber from waste tires at $180^{\circ} \mathrm{C}$. The test method was farther developed of a method employed in adhesion science for measurement of the diffusion and solubility coefficients of water in adhesive. The values of the diffusion and solubility coefficients were found to be of the same order as those report in the literature for water adhesive systems on the basis of current tests.

Parmeet Singh, Akashpathania (May 2018) "Modification of bitumen (using crumb rubber and MICA): A case on udhampur and ramban road" This study investigated the influence of crumb rubber and mica on the physical performance and mechanical properties of bitumen binder. Crumb rubber sieved through $700 \mu \mathrm{m}$ sieve. Both crumb rubber and mica impact hardness, strength and rigidity to the virgin bitumen. crumb rubber was blended in to bitumen in variation of $3 \%, 5 \%$ and $7 \%$ by weight of sample mica was blended in the bitumen in variation of $35 \%, 45 \%$ and $55 \%$ of the weight of sample. Since it is hilly region, design speed of the weight of sample. Since it is hilly region, design speed of the weight of the vehicle cannot exceed 70-80 kmph.

Davide Lo Presti ( Dec 2013) " Recycled tire rubber modified bitumen for road asphalt mixtures : A Literature review" In terms of binder properties the main difference between these products are the viscosity and their storage stability viscosity for no agitation RTE $-\mathrm{MB}$ can range between 500 and 1000centipoises at $135^{\circ} \mathrm{C}$ much lower than the range of $1500-5000$ centipoise at $177.5^{\circ} \mathrm{C}$ with regards the stability no- agitation R TR- MB born with the idea of obtaining a RTR-MB modified binder comparable to the normal PMBS therefore on contrary to high viscosity RTR-MB it is usually possible to store its as conventional PMBS. Furthermore a recent study. Highlight that the storage temperature non agitated RTR-MB could be significantly decreased it compared to the need of the field blends to be stored in agitated tank from this point of view the terminal blends leads tanks to significant energy and money saving.

Prof.S.B.Patil (Dec- 2016) "Use of waste tire in road construction" This study investigated the modified bitumen and granulated (or) grand rubber (or) crumb rubber can be used as a portion of the fine stone aggregate a mixture of hot bitumen and crumb rubber derived from post -consumer waste or scrap tire. It is a material that can be used to seal crack and joints be applied as a chip seal coat and added to hot mineral aggregate to make a unique asphalt paving material.

Nithishkumar. K, Dr.HN.Rajakumara (May 2016) "Study of using rubber tire in construction of bitumen our road" This study investigate the replaced in bitumen and aggregate should be achieve the stability and strengthening. This paper is intended to study the feasibility of the waste tire rubber as a blending material in bitumen and its mix which is used for road construction. The present study has been carried out in two stage. In the first stage basic property of bitumen is modified by adding the crumb rubber in $1-4 \%$. In the second stage strength property of bitumen mix is determination by adding crumb rubber up to $1-4 \%$ with bitumen and replacing aggregate from 5-15\% with waste rubber aggregate. The grade of bitumen used in study is VG30. The result property of VG30 bitumen is within the permissible limit by adding $0.4 \%$ rubber in bitumen the values of specific gravity, softening point flash \& fire point are increase and ductility, penetration values are decrease but up to $1 \%$ addition of crumb rubber. Stability and flow of bitumen mi are within the limit up to $1 \%$ of crumb rubber. By replacing 5\% aggregate by rubber aggregate the Marshall stability and flow values are within optimum limit.

\section{METHODOLOGY}

The proposed methodology is depicted a flowchart in the

Fig: 4.1

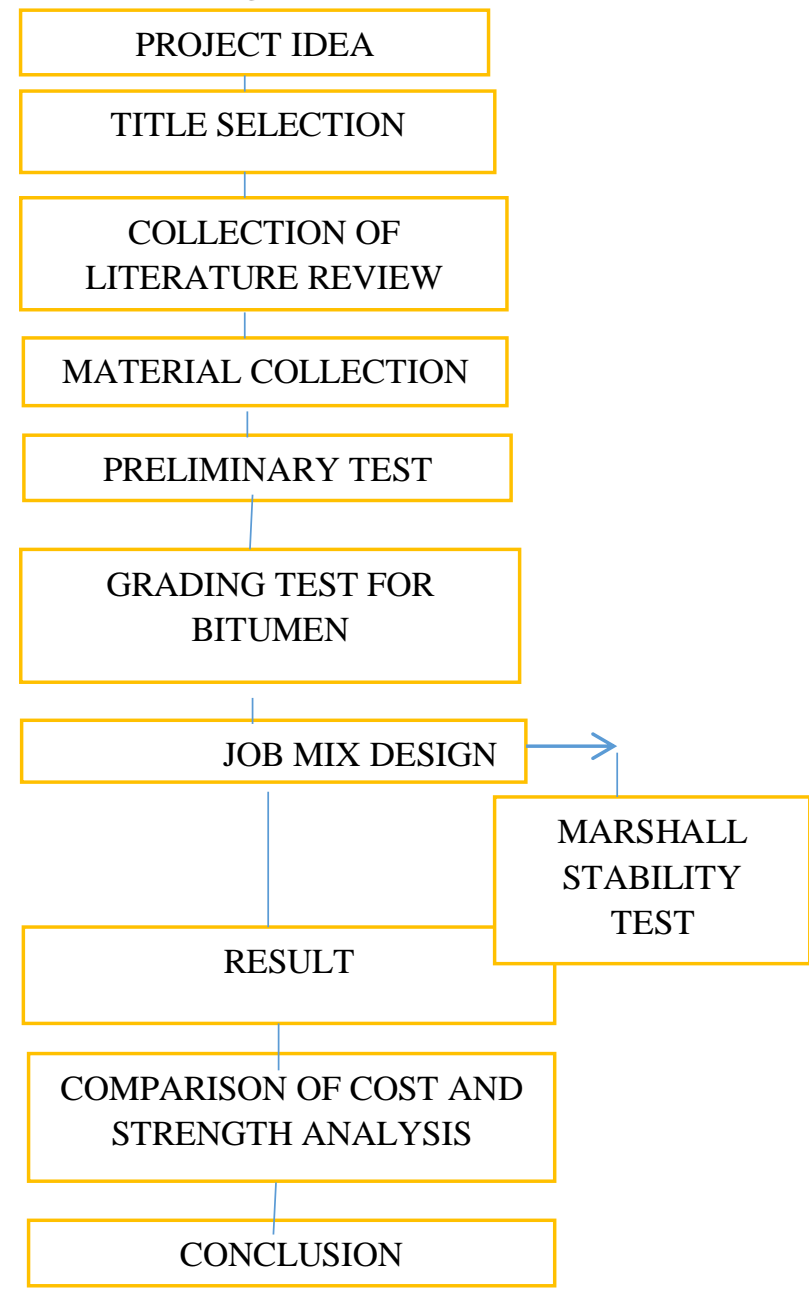




\section{V.MATERIALS USED}

The basic materials used for our project are Bitumen, Aggregate, Rubber tire, Glass fiber are the basic constituents of materials vary from place to place.

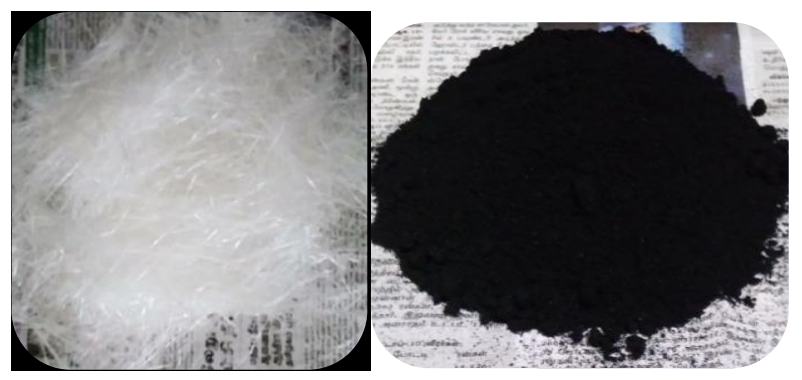

Glass fiber, Tire rubber

\section{PRIMARY TESTS ON MATERIALS}

1.Specific gravity test on coarse aggregate

\begin{tabular}{|l|l|l|l|}
\hline 1. & $\begin{array}{l}\text { BULK } \\
\text { SPECIFIC } \\
\text { GRAVITY }\end{array}$ & $\begin{array}{l}\text { APPARENT } \\
\text { SPECIFIC } \\
\text { GRAVITY }\end{array}$ & $\begin{array}{l}\text { EFFECTIVE } \\
\text { SPECIFIC } \\
\text { GRAVITY }\end{array}$ \\
\hline
\end{tabular}

2.Impact test on aggregates $=17.7 \%$

3. Water absorption $\quad=0.55 \%$

4.Combined aggregate grading (\%passing)

We are using the aggregate size given the below

$19 \mathrm{~mm}$ aggregate $\mathrm{CA} 1=21 \%, 6 \mathrm{~mm}$ aggregate $\mathrm{CA} 3=19 \%$

$13.2 \mathrm{~mm}$ aggregate $\mathrm{CA} 2=27 \%$, Dust $\mathrm{CS}=33 \%$

$$
\text { Total }=100 \%
$$

\section{Combined grading result of coarse aggregate}

\begin{tabular}{|c|c|c|c|c|c|c|c|}
\hline $\begin{array}{l}\text { SIEVE } \\
\text { SIZE(mm) }\end{array}$ & $\mathbf{C A}_{1}$ & $\mathbf{C A}_{2}$ & $\mathrm{CA}_{3}$ & CS & CEMENT & LIMITS & $\begin{array}{l}\text { COMBINED } \\
\text { GRADING }\end{array}$ \\
\hline $265 \mathrm{~mm}$ & $0 \%$ & $0 \%$ & $0 \%$ & $0 \%$ & $0 \%$ & 0 & $0.00 \%$ \\
\hline $19 \mathrm{~mm}$ & $21.00 \%$ & $27 \%$ & $19 \%$ & $33.00 \%$ & $0 \%$ & 100 & $100.00 \%$ \\
\hline $13.2 \mathrm{~mm}$ & $13.93 \%$ & $26.95 \%$ & $19 \%$ & $33.00 \%$ & $0 \%$ & $90-100$ & $92.88 \%$ \\
\hline $9.5 \mathrm{~mm}$ & $1.18 \%$ & $20.83 \%$ & $19 \%$ & $33.00 \%$ & $0 \%$ & $70-88$ & $74.01 \%$ \\
\hline $4.75 \mathrm{~mm}$ & $0 \%$ & $9.34 \%$ & $\begin{array}{l}18.69 \\
\%\end{array}$ & $32.98 \%$ & $0 \%$ & $53-71$ & $61.01 \%$ \\
\hline $2.36 \mathrm{~mm}$ & $0 \%$ & $6.65 \%$ & $5.86 \%$ & $32.35 \%$ & $0 \%$ & $42-58$ & $44.85 \%$ \\
\hline
\end{tabular}

\begin{tabular}{|c|c|c|c|c|c|c|c|}
\hline $1.18 \mathrm{~mm}$ & $0 \%$ & $6.06 \%$ & $4.67 \%$ & $23.29 \%$ & $0 \%$ & $34-48$ & $34.03 \%$ \\
\hline $0.6 \mathrm{~mm}$ & $0 \%$ & $0 \%$ & $5.35 \%$ & $22.51 \%$ & $0 \%$ & 26-38 & $27.85 \%$ \\
\hline $0.3 \mathrm{~mm}$ & $0 \%$ & $0 \%$ & $3.90 \%$ & $14.23 \%$ & $0 \%$ & $18-28$ & $18.13 \%$ \\
\hline $\begin{array}{l}0.15 \mathrm{~m} \\
\mathrm{~m}\end{array}$ & $0 \%$ & $0 \%$ & $\begin{array}{l}3.58 \\
\%\end{array}$ & $\begin{array}{l}8.85 \\
\%\end{array}$ & $0 \%$ & $12--20$ & $12.43 \%$ \\
\hline $\begin{array}{l}0.075 \mathrm{~m} \\
\mathrm{~m}\end{array}$ & $0 \%$ & $0 \%$ & $\begin{array}{l}1.57 \\
\%\end{array}$ & $\begin{array}{l}3.50 \\
\%\end{array}$ & $0 \%$ & 04--10 & $5.07 \%$ \\
\hline
\end{tabular}

"The test conducted as per is 2386 part -1 (1963) conforms as per Morth V revision"

\section{JOB MIX DESIGN}

\section{Weight of material for Bituminous Concrete mould}

Various sizes of aggregate required

$\begin{array}{ll}\text { 19mm aggregate } & -21 \% \\ \text { 13.2mm aggregate } & -27 \% \\ \text { 6mm aggregate } & -19 \% \\ \text { Dust } & -\underline{33 \%} \\ \text { Total } & =100 \%\end{array}$

Various percentages and weights of fine and coarse aggregate

As per the Morth 1200 is taken as BC mould:

$$
\begin{array}{ll}
19 \mathrm{~mm}(21 \%)=\frac{21}{100} \times 1200 & =252 \mathrm{gms} \\
13.2 \mathrm{~mm}(27 \%)=\frac{27}{100} \times 1200 & =324 \mathrm{gms} \\
6 \mathrm{~mm}(19 \%)=\frac{19}{100} \times 1200 & =228 \mathrm{gms} \\
\text { Dust }(33 \%)=\frac{33}{100} \times 1200 & =396 \mathrm{gms} \\
\text { Total fine and coarse aggregate }=1200 \mathrm{gms} & =66 \mathrm{gms} \\
\text { Bitumen weight }=\frac{5.5}{100} \times 1200 &
\end{array}
$$

(5.5\% by weight of coarse and fine aggregate)

Total mix $=$ Total fine and coarse+bitumen 


$$
=1200+66=1266 \mathrm{gms}
$$

$5 \%$ of tire rubber with bitumen content

62.7gms(bitumen)

$$
=66 \times 5 \%=3.3 \mathrm{gms}(\text { tire rubber }),
$$

Similar to the glass fiber

$10 \%$ of tire rubber with bitumen content

$59.4 \operatorname{gms}($ bitumen $)$

$$
=66 \times 10 \%=6.6 \mathrm{gms}(\text { tire rubber }),
$$

Similar to the glass fiber

Normal bitumen and modified bitumen in various materials with various percentages and we get various results in job mix test.

\section{RESULT AND CONCLUSION}

\section{Result of grading test on bitumen}

\begin{tabular}{|l|l|l|l|l|}
\hline S.No & tests & results & Rangs & IS code \\
\hline 1 & $\begin{array}{l}\text { Penetration } \\
\text { test }\end{array}$ & $96 \mathrm{~mm}$ & $\begin{array}{l}\text { Min } \\
45 \mathrm{~mm}\end{array}$ & Is 1203 \\
\hline 2 & Ductility test & $65 \mathrm{~mm}$ & $\begin{array}{l}\text { Min } \\
40 \mathrm{~mm}\end{array}$ & Is 1203 \\
\hline 3 & $\begin{array}{l}\text { Softening } \\
\text { point test }\end{array}$ & $48 \mathrm{~mm}$ & $\begin{array}{l}\text { Min } \\
47 \mathrm{~mm}\end{array}$ & Is1205 \\
\hline 4 & $\begin{array}{l}\text { Specific } \\
\text { gravity }\end{array}$ & 1.03 & $0.9-1.09$ & Is 1202 \\
\hline
\end{tabular}

"The conforms as per IS73-2013 .(VG 30)"

Flexible pavement Properties ranges in mixture "As per Morth V Revision"

\begin{tabular}{|l|l|l|}
\hline S.No & PROPERTIES & RANGE \\
\hline 1 & Stability & Min 900kg \\
\hline 2 & Flow value & $2-4 \mathrm{~mm}$ \\
\hline 3 & \% air voids & $3-6$ \\
\hline 4 & $\begin{array}{l}\text { \%Voids filled with } \\
\text { bitumen (VFB) }\end{array}$ & $65-75$ \\
\hline
\end{tabular}

\begin{tabular}{|l|l|l|}
\hline 5 & $\begin{array}{l}\text { \%Voids in minerals } \\
\text { aggregate }\end{array}$ & $12-14$ \\
\hline
\end{tabular}

1. Result of Stability value for normal bitumen with waste materials

\begin{tabular}{|l|l|l|l|}
\hline S.No & $\begin{array}{l}\text { PERCENTAGE } \\
\text { OF SAMPLE }\end{array}$ & $\begin{array}{l}\text { STABILITY } \\
\text { FOR TIRE } \\
\text { RUBBER } \\
\text { (kg) }\end{array}$ & $\begin{array}{l}\text { STABILITY } \\
\text { FOR } \\
\text { GLASS } \\
\text { FIBER (kg) }\end{array}$ \\
\hline 1 & Optimum ( 0\%) & 920 & 920 \\
\hline 2 & $\begin{array}{l}\text { bitumen with 5\% } \\
\text { Waste materials }\end{array}$ & 1685 & 3494.2 \\
\hline 3 & $\begin{array}{l}\text { bitumen with } \\
\text { materials }\end{array}$ & 1656 & 2758 \\
\hline
\end{tabular}

\begin{tabular}{|c|c|c|c|}
\hline $\begin{array}{l}\text { S. } \\
\text { No }\end{array}$ & $\begin{array}{l}\text { PERCENTAGE } \\
\text { OF SAMPLE }\end{array}$ & $\begin{array}{l}\text { FLOW } \\
\text { VALUE } \\
\text { FOR } \\
\text { TIRE } \\
\text { RUBBER } \\
(\mathbf{m m})\end{array}$ & $\begin{array}{l}\text { FLOW } \\
\text { VALUE } \\
\text { FOR } \\
\text { GLASS } \\
\text { FIBER } \\
(\mathrm{mm})\end{array}$ \\
\hline 1 & Optimum & 3.3 & 3.3 \\
\hline 2 & $\begin{array}{l}\text { Bitumen with } \\
5 \% \text { waste } \\
\text { materials }\end{array}$ & 6.2 & 7.3 \\
\hline 3 & $\begin{array}{l}\text { Bitumen with } \\
10 \% \text { waste } \\
\text { materials }\end{array}$ & 7.3 & 6.9 \\
\hline
\end{tabular}

2. Result of flow value for normal bitumen with waste materials 


\begin{tabular}{|l|l|l|l|}
\hline S.No & $\begin{array}{l}\text { PERCENTAGE } \\
\text { OF SAMPLE }\end{array}$ & $\begin{array}{l}\text { (Va) FOR } \\
\text { TIRE } \\
\text { RUBBER }\end{array}$ & $\begin{array}{l}\text { (Va) FOR } \\
\text { GLASS } \\
\text { FIBER }\end{array}$ \\
\hline 1 & Optimum & 5.938 & 5.938 \\
\hline 2 & $\begin{array}{l}\text { Bitumen with5\% } \\
\text { waste materials }\end{array}$ & 3.511 & 1.213 \\
\hline 3 & $\begin{array}{l}\text { Bitumen with } \\
10 \% \text { waste } \\
\text { materials }\end{array}$ & 4.464 & 2.77 \\
\hline
\end{tabular}

FLOW VALUE FOR NORMAL BITUMEN WITH

VARIOUS PERCENTAGE WASTE MATERIALS

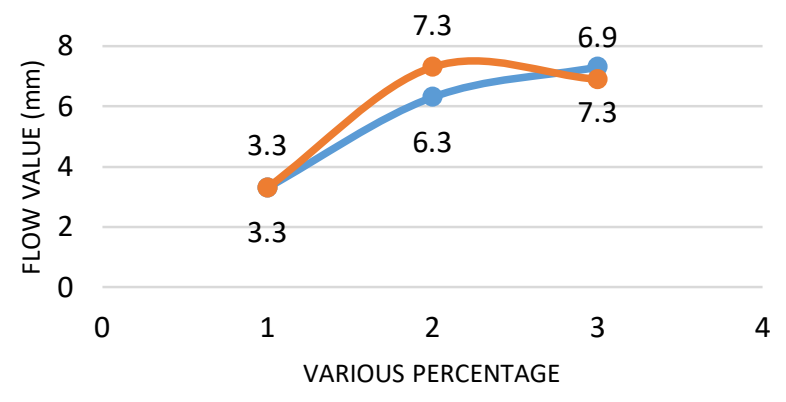

tire rubber $\longrightarrow$ glass fiber

3. Result of bulk density for normal bitumen with waste materials

\begin{tabular}{|l|l|l|l|}
\hline $\begin{array}{l}\text { S. } \\
\text { No }\end{array}$ & $\begin{array}{l}\text { PERCENTAGE } \\
\text { OF SAMPLE }\end{array}$ & $\begin{array}{c}\text { BULK } \\
\text { DENSITY OF } \\
\text { COMPACTED } \\
\text { MIXTURE } \\
\text { FOR TIRE } \\
\text { RUBBER (g/cc) }\end{array}$ & $\begin{array}{c}\text { BULK } \\
\text { DENSITY } \\
\text { OF } \\
\text { COMPACT } \\
\text { ED } \\
\text { MIXTURE } \\
\text { FOR GLASS } \\
\text { FIBER(g/cc) }\end{array}$ \\
\hline 1 & Optimum & 2.170 & 2.170 \\
\hline 2 & $\begin{array}{l}\text { Bitumen with 5\% } \\
\text { waste materials }\end{array}$ & 2.226 & 2.347 \\
\hline 3 & $\begin{array}{l}\text { Bitumen with } \\
10 \% \text { waste } \\
\text { materials }\end{array}$ & 2.204 & 2.330 \\
\hline
\end{tabular}

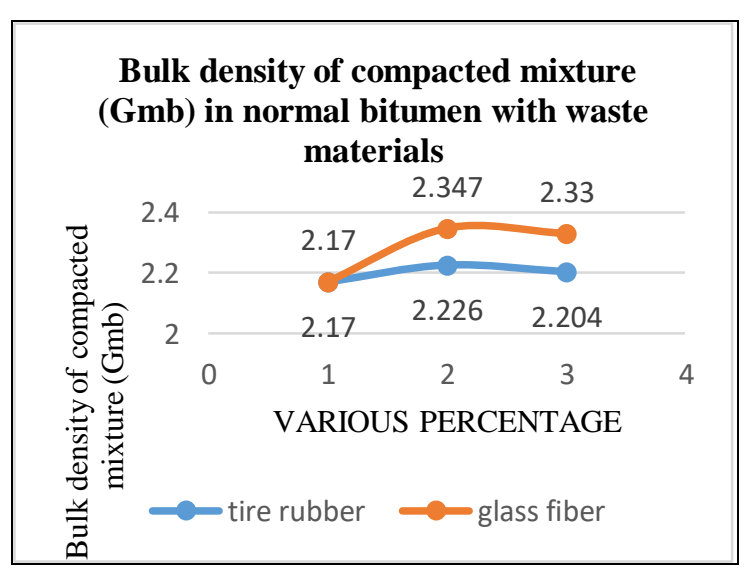

5.Result of Percent air voids in compacted mixture (Va)

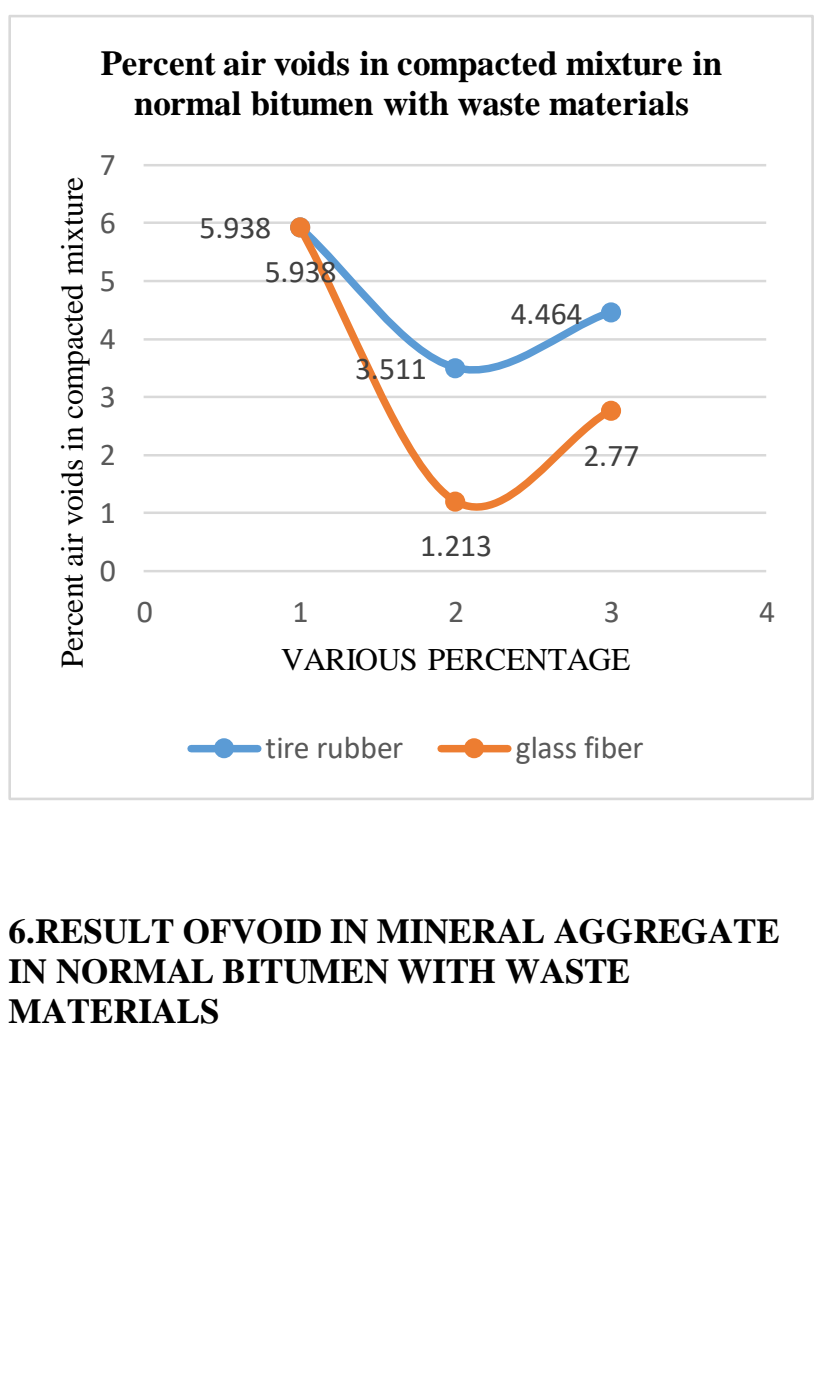




\begin{tabular}{|l|l|l|l|}
\hline S.No. & $\begin{array}{l}\text { PERCENTAGE } \\
\text { OF SAMPLE }\end{array}$ & $\begin{array}{l}\text { (VMA) } \\
\text { FOR } \\
\text { TIRE } \\
\text { RUBBER }\end{array}$ & $\begin{array}{l}\text { (VMA) } \\
\text { FOR } \\
\text { GLASS } \\
\text { FIBER }\end{array}$ \\
\hline 1 & Optimum & 13.758 & 13.758 \\
\hline 2 & $\begin{array}{l}\text { Bitumen with 5\% } \\
\text { waste materials }\end{array}$ & 14.314 & 12.275 \\
\hline 3 & $\begin{array}{l}\text { Bitumen with } \\
10 \% \text { waste } \\
\text { materials }\end{array}$ & 15.161 & 13.66 \\
\hline
\end{tabular}

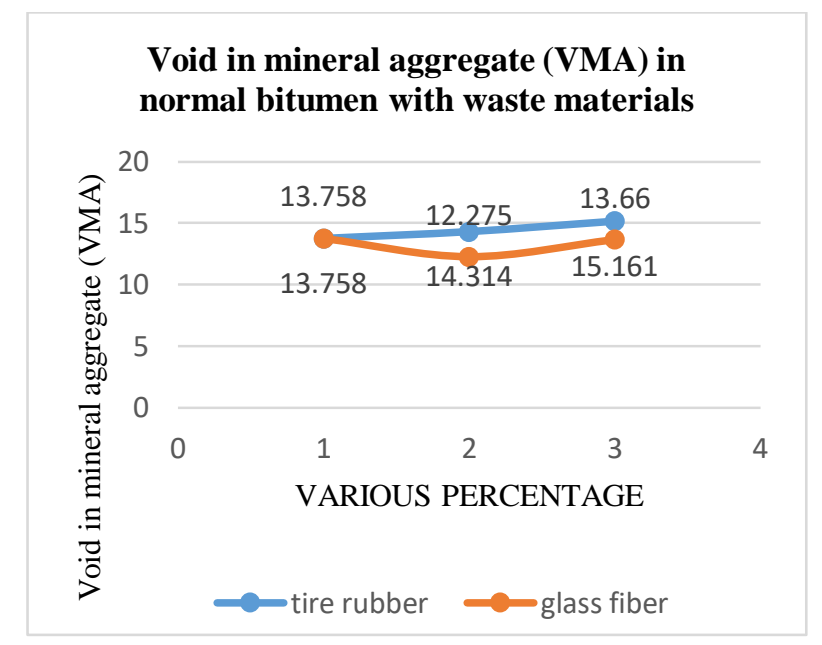

\section{RESULT OF VOID FILLED WITH BITUMEN IN WASTE MATERIALS}

\begin{tabular}{|l|l|l|l|}
\hline $\begin{array}{l}\text { S. } \\
\text { No. }\end{array}$ & $\begin{array}{l}\text { PERCENTAGE } \\
\text { SAMPLE }\end{array}$ & $\begin{array}{l}\text { (VFB) } \\
\text { FOR } \\
\text { TIRE } \\
\text { RUBBER } \\
\text { (VFB) FOR } \\
\text { GLASS } \\
\text { FIBER }\end{array}$ \\
\hline 1 & Optimum & 66.560 & 66.560 \\
\hline 2 & $\begin{array}{l}\text { 5\% bitumen with } \\
\text { waste materials }\end{array}$ & 74.895 & 90.12 \\
\hline 3 & $\begin{array}{l}\text { 10\% bitumen } \\
\text { with waste } \\
\text { materials }\end{array}$ & 70.556 & 83.58 \\
\hline
\end{tabular}

Voids filled bitume

\section{COST ANALYSIS OF NORMAL PAVEMENT WITH WASTE MATERIALS}

Government rate of normal flexible pavement with tire rubber

Normal flexible pavement of $10 \mathrm{~m}^{2}$ area quantity

$$
=\operatorname{Rs} 1815.85
$$

Normal flexible pavement with 5\% tire rubber

$$
=\operatorname{Rs} 1760.35
$$

Normal flexible pavement with $10 \%$ tire rubber

$$
=\operatorname{Rs} 1705.15
$$

Private rate of normal flexible pavement with tire rubber

Normal flexible pavement of $10 \mathrm{~m}^{2}$ area quantity

$$
=\text { Rs } 2265.63
$$

Normal flexible pavement with $5 \%$ tire rubber

$$
=\text { Rs } 2187.56
$$

Normal flexible pavement with $10 \%$ tire rubber

$$
=\text { Rs } 2109.45
$$

Government rate of normal flexible pavement with glass fiber

Normal flexible pavement of $10 \mathrm{~m}^{2}$ area quantity

$$
=\text { Rs } 1815.85
$$

Normal flexible pavement with 5\% glass fiber

$$
=\text { Rs } 2347.99
$$

Normal flexible pavement with $10 \%$ glass fiber 
International Journal of Innovative Research in Applied Sciences and Engineering (IJIRASE) Volume 3, Issue 9, DOI: 10.29027/IIIRASE.v3.i9.2020, 519-526, March 2020

$=$ Rs 2880.43

Private rate of normal flexible pavement with tire rubber

Normal flexible pavement of $10 \mathrm{~m}^{2}$ area quantity

$$
=\text { Rs } 2265.63
$$

Normal flexible pavement with $5 \%$ glass fiber

$$
=\operatorname{Rs} 2775.2
$$

Normal flexible pavement with $10 \%$ glass fiber

$$
=\operatorname{Rs} 3284.73
$$

The various percentage shown in $0 \%, 5 \%, 10 \%$ representative of 1,2,3 in the bar chart.

The government and private rate of normal bitumen with waste materials results in shown in bar chart fig 5,6

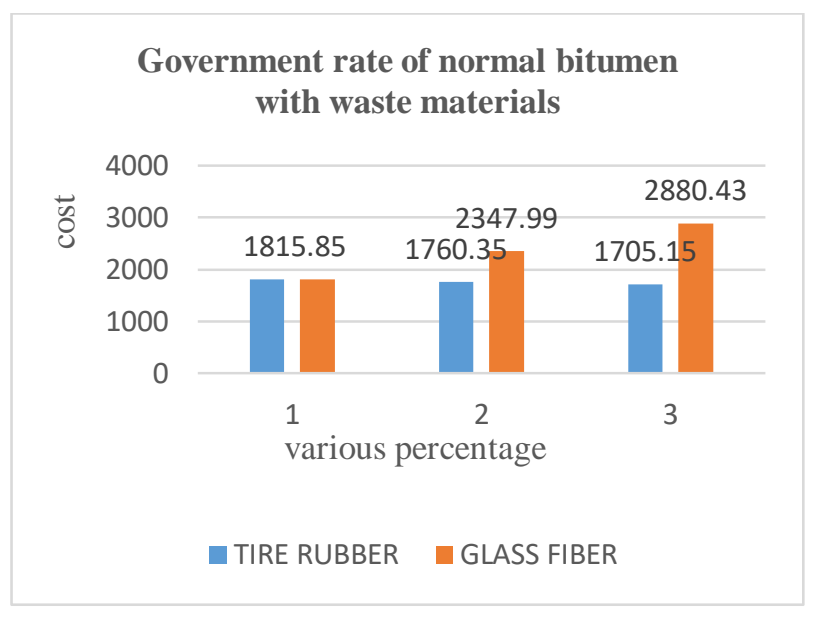

Fig 5 :The government rate of normal flexible pavement with waste materials

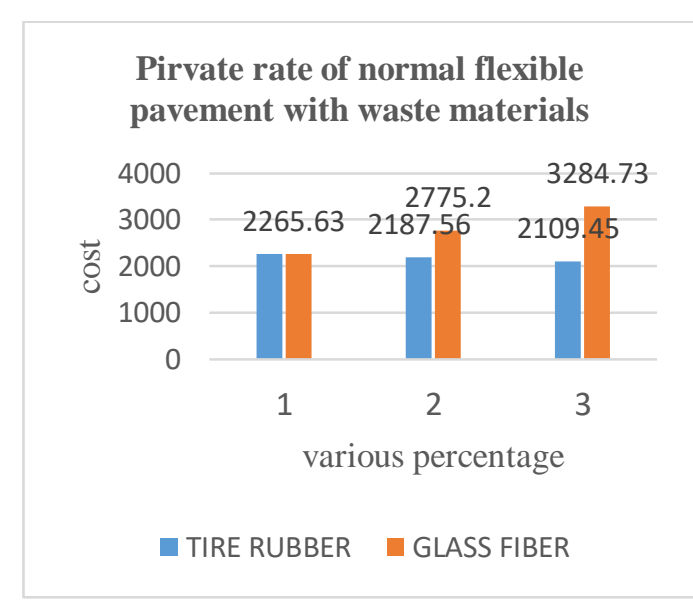

Fig 6: Private rate of normal flexible pavement with waste materials

\section{CONCLUSION}

We are concluded here for our project is to minimize the cost of the pavement, reduced the wastes at the same time to increase its durability, strength, smoothness and resist slippery action of the pavement and also to resist the failure. We are compared the normal bitumen and adding various waste material to check how the strength can be achieved and finding the stability and flow value of bitumen with tire rubber, glass fiber and it is the important test for the flexible pavement. The range of the bitumen for taking up to optimum, 5\%, 10\% of tire rubber and glass fiber.The main theme of our project is to reduce the cost, reduces the wastes, reduce the maintenance work.our project only done by the waste materials such as tire rubber and glass fiber. These can taken more time to degrade and it causes damages to human beings so it can be adding additives to the bitumen. By adding these additives it gives aesthetics, flexibility and increasing lifetime of the flexible pavement.

\section{REFERENCES}

1. Mohd rosli hainin(oct-2016) "Alternative Binders For Flexible Pavement", ARPN Journal Of Engineering And Applied Sciences, Volume 11,No.20

2. Mohamed Abdel Raouf , Mohamed Metwally(oct-2010) "Development of non-petroleum based binder for using flexible pavements" IOWA STATE UNIVERSITY Institute of transportation

3. Amit Goel (aug-2014) "Emerging road materials and innovative applications" , national conference on materials and their application in civil engineering, volume 10

4. K.Sri Harsha(Apr-2017) "Partial replacement of bitumen with glass fibre in flexible pavement", International journal of civil engineering and technology(IJCIET), volume 8, Issue: 4 
5. Megha Deshmukh(Jul-2016) "Quality improvement practices in bituminous road construction", International research journal of engineering and technology(IRJET), volume 03, Issue:7

6. Melik Bekhiti (2014) " Properties of waste tire rubber powder", Engineering ,Technology \& Applied Science Research, Volume 4 Issue :4

7. Megha Deshmukh(Jul-2016) "Quality improvement practices in bituminous road construction", International research journal of engineering and technology(IRJET), volume 03, Issue: 7

8. Mohd rosli hainin(oct-2016) "Alternative Binders For Flexible Pavement", ARPN Journal Of Engineering And Applied Sciences, Volume 11, No. 20

9. Mohamed Abdel Raouf , Mohamed Metwally(oct-2010) "Development of non-petroleum based binder for using flexible pavements" IOWA STATE UNIVERSITY Institute of transportation

10. Nithu(2017) "Utilization of rubber waste in construction of flexible pavement", International journal of advanced research and development, volume 2, Issue: 7 